\section{Performance, Carcass Yield, and Qualitative Characteristics of Breast and Leg Muscles of Broilers Fed Diets Supplemented with Vitamin $E$ at Different Ages}

\begin{tabular}{l} 
Q Author(s) \\
\hline \\
Leonel FR ${ }^{1 a^{*}}$ \\
Oba $A^{1}$ \\
Pelicano $E R L^{1}$ \\
Zeola $\mathrm{NMBL}^{1}$ \\
Boiago $\mathrm{MM}^{1}$ \\
Scatolini $\mathrm{AM}^{1}$ \\
Lima TMA \\
Souza PA ${ }^{1}$ \\
Souza HBA ${ }^{1 b}$ \\
\\
1 FCAV/Unesp \\
a Animal Scientist, Master in Animal Science, \\
PhD student. \\
b Professor, Technology Department, FCAV/ \\
UNESP.
\end{tabular}

\section{Mail Address}

\section{FR Leonel}

Via de Acesso Prof. Paulo Donato Castellane, $s / n$

Departamento de Tecnologia,

14.884-900. Jaboticabal, SP, Brazil.

Phone: +55 +16 3209-2675 ext. 245

E-mail: leonel@fcav.unesp.br

\section{Keywords}

Broiler chickens, meat quality, vitamin $\mathrm{E}$.

\section{Acknowledgments}

The authors thank Universidade Estadual Paulista Júlio de Mesquita Filho - FCAV/ Jaboticabal, for providing research opportunity, and CAPES for providing a scholarship for the author, and FAPESP for research grants.

\section{ABSTRACT}

The effects of vitamin E supplementation $(300 \mathrm{mg} / \mathrm{kg}$ diet) in the diet of broiler chickens for different periods during rearing on the performance and qualitative traits of breast and leg muscles were evaluated. Seven hundred and twenty day-old chicks were distributed into six treatments: basal diet (25 mg vitamin $\mathrm{E} / \mathrm{kg}$ diet), and diet supplemented with vitamin E from 1 to 15,1 to 30, 1 to 45, 14 to 45 and 30 to 45 days of age. Vitamin E content, lipid percentage, TBARS ( 0 and 3 days of storage), color $(* \mathrm{~L}, * a, * b)$, and $\mathrm{pH}$ were evaluated. There were no differences $(p>0.05)$ among treatments in performance, carcass yield, and cut yields. Qualitative parameters ( $\mathrm{pH}$ and color) presented no differences, although vitamin E positively affected TBARS values at 3 days of storage, mainly in leg muscles. Vitamin E levels in both muscles were higher in the birds supplemented throughout the experiment.

\section{INTRODUCTION}

Considering consumers' requirements as to product quality, and considering that Brazil is one of the largest poultry producers and exporters, it is crucial to maintain the quality of chicken products. The loss of quality is more evident in fatty acid-rich meat, such as pork, beef, and poultry meat products. Many studies on the use of natural and artificial antioxidants have been conducted (Papas, 1993) with the aim of reducing losses, especially during storage due to lipid oxidation, which is considered one of the major causes of deterioration of meat and meat products (Pearson et al., 1983).

As a result of lipid oxidation, many undesirable degradation products are released, resulting in the typically unpleasant odour and taste of rancid meat.

Vitamin E has many functions and has been used in animal feeding. Undoubtedly, its role as antioxidant is the most important, and protects the muscle from peroxidation. Thus, it is known that diets supplemented with vitamin $\mathrm{E}$ are used in order to diminish lipid oxidation in muscle.

Among the various forms of vitamin $\mathrm{E}$, á-tocopherol is up to 15 times more powerful as antioxidant (Burton et al., 1983). In addition, the accumulation of vitamin $\mathrm{E}$ in tissues is related to dietary supplementation levels during pre-slaughter period in broilers (Asghar et al., 1990; Lauridsen et al., 1997). It was shown that cell membrane stabilization caused dietary vitamin $\mathrm{E}$ prevents the onset of lipid oxidation in poultry meat (Yamauchi et al., 1991) and pork (Monahan et al., 1993).

Lauridsen et al. (1997) evaluated breast and leg meat from broilers fed diets with $10 \%$ lard or olive oil, and two levels of vitamin E (20 or $200 \mathrm{mg} / \mathrm{kg}$ diet). Oxidative stability of the membrane fraction tended to increase with increasing levels of á-tocopherol in muscle samples, indicating that dietary vitamin $\mathrm{E}$ promoted higher stability in regard to oxidation. Higher vitamin E levels were also described as a reliable 
Leonel FR, Oba A, Pelicano ERL, Zeola NMBL, Boiago MM, Scatolini AM, Lima TMA, Souza PA, Souza HBA
Performance, Carcass Yield, and Qualitative Characteristics of Breast and Leg Muscles of Broilers Fed Diets Supplemented w ith Vitamin E at Different Ages measure to improve broiler health status, and, consequently, broiler performance. The increase in processed meat consumption as compared to fresh meat has economic advantages when vitamin addition strategies (ante-mortem or post-mortem) are used, reducing deterioration during storage, or improving meat qualitative traits (Lahucky et al., 2005). The present study evaluated the effects of vitamin $E$ supplementation (300 $\mathrm{mg} / \mathrm{kg}$ diet) in the diets of broiler chickens during different periods ofrearing on performance and carcass and cuts quality .

\section{MATERIAL AND METHODS}

\section{Location}

The experiment was conducted at the Poultry Sector from the Department of Animal Science of Faculdade de Ciências Agrárias e Veterinárias, FCAV/Unesp, Jaboticabal, São Paulo, Brazil. Laboratorial analyses were conducted at Laboratory of Animal Food Technology from the Department of Technology of the same institution.

\section{Animals and Husbandry}

Seven hundred and twenty male Cobb chicks from one to 42 days of age were reared according to standard husbandry practices used in commercial broiler farms. Feed and water were provided ad libitum throughout the experimental period. Rearing period was divided into three phases, i.e., starter (1 to 21 days), grower (22 to 35 days), and finisher (36 to 45 days). Diets (Table 1) were formulated according to Rostagno (2000). Birds were slaughtered in a commercial slaughterhouse according to standard procedures (stunning, bleeding, scalding for 3 minutes at $54^{\circ} \mathrm{C}$, defeathering, and evisceration). Carcass yield and cut yield were calculated using carcass and cuts weights before and after chilling .

\section{Experimental design and treatments}

A completely randomized experimental design was used, consisting of 6 treatments, 4 repetitions, with 30 birds in each experimental unit. Treatments included a non-supplemented basal diet (25 mg vitamin $\mathrm{E} / \mathrm{kg}$ ) and a diet supplemented with vitamin E (300 mg vitamin E/ $\mathrm{kg}$ diet) fed from 1 to 15 days of age, 1 to 30 days of age, 1 to 45 days, 15 to 45 days, or 30 to 45 days of age. At 45 days of age, production indexes and yields (carcass and cuts) were calculated. Data were submitted to analysis of variance and means were compared using the test of Tukey at $5 \%$ of significance.

\begin{tabular}{|c|c|c|c|}
\hline Ingredients (\%) & $\begin{array}{c}\text { Starter } \\
\text { (1-21 days) }\end{array}$ & $\begin{array}{c}\text { Grower } \\
\text { (22-35 days) }\end{array}$ & $\begin{array}{l}\text { Finisher } \\
\text { (36-45 days) }\end{array}$ \\
\hline Corn & 54.50 & 59.30 & 61.30 \\
\hline Soybean meal & 36.80 & 31.20 & 28.00 \\
\hline Oil & 3.70 & 4.50 & 5.70 \\
\hline Premix & 5.00 & 5.00 & 5.00 \\
\hline Total & 100.0 & 100.0 & 100.0 \\
\hline \multicolumn{4}{|l|}{ Calculated composition } \\
\hline ME (kcal/kg) & 3,000 & 3,100 & 3,200 \\
\hline Crude protein (\%) & 21.40 & 19.30 & 18.20 \\
\hline Lysine $(\%) 1.14$ & 1.05 & 0.94 & \\
\hline Methionine (\%) & 0.49 & 0.45 & 0.41 \\
\hline Methionine + cysteine (\%) & 0.81 & 0.74 & 0.67 \\
\hline Calcium (\%) & 0.96 & 0.87 & 0.80 \\
\hline Available phosphorus (\%) & 0.45 & 0.41 & 0.37 \\
\hline Sodium $(\%)$ & 0.22 & 0.19 & 0.19 \\
\hline
\end{tabular}

Premix - Composition per kg of product: Vit. A 176,000 IU, Vit. D3 40,000 IU, Vit. E $500 \mathrm{mg}$, Vit. K3 $100 \mathrm{mg}$, Vit. B1 $36 \mathrm{mg}$, Vit.B2 $200 \mathrm{mg}$, Vit.B6 50mg, Vit. B12 $560 \mathrm{mcg}$, Niacin $700 \mathrm{mg}$, Biotin 3mg, Pantothenic acid $500 \mathrm{mg}$, Folic acid $30 \mathrm{mg}$, Choline $20 \mathrm{~g}$, Iron $1,1000 \mathrm{mg}$, Copper $300 \mathrm{mg}$, Manganese $1,800 \mathrm{mg}$, Zinc $1.200 \mathrm{mg}$, lodine $24 \mathrm{mg}$, Selenium $3 \mathrm{mg}$, Methionine $20 \mathrm{~g}$, Calcium $176 \mathrm{~g}$, Phosphorus 68g, Sodium 23g, Chloride $36 \mathrm{~g}$, Growth promoter $2 \mathrm{~g}$ (Avilamycin), Anticoccidial $10 \mathrm{~g}$, Antifungal 200mg, Antioxidant $1 \mathrm{~g}$ (BHT), Excipient (q.s.p) 1,000g.

\section{Laboratorial analyses}

Two birds from each replicate (8 birds per treatment) were randomly submitted to laboratory analyses, which included TBARS (thiobarbituric acid-related substances), colour, pH, lipid percentage, fatty acid profile, and vitamin E content in breast and leg muscles (thighs and drumsticks). TBARS analysis (oxidation) was performed in raw meat as described by Pikul et al. (1989), both at slaughter and after 3 days storage at $4^{\circ} \mathrm{C}$. Color was determined using a Minolta Chrome Meter CR-300 according to CIELAB system, which provides values relative to $L^{*}$ (luminosity), a* (redness), and $b^{*}$ (yellowness). $\mathrm{pH}$ was measured in triplicate, using a digital insertion pHmeter (TESTO). Vitamin E levels were determined in triplicate: samples were frozen in liquid nitrogen after slaughter, and submitted to HPLC with mobile phase column (n-hexane/isopropanolol 95/ 5) at $1.5 \mathrm{ml} / \mathrm{min}$ (Brubacher; Muller-M ulot; Southgate, 1985). Fatty acids were determined in triplicate after methylation and extraction (Bly \& Dyer, 1959), and gas chromatography (Shimadzu). An Omegawax 250 Fused Silica Capillary Column $(30 \mathrm{mx0} .25 \mathrm{~mm} \times 0.25 \mu \mathrm{m})$ with standard (Sigma, cat. 189-19) was used. Lipid contents in muscle samples were determined in triplicate according to AOAC (1995).

\section{RESULTS}

There were no differences $(p>0.05)$ between treatments as to feed intake, weight gain, feed 
Leonel FR, Oba A, Pelicano ERL, Zeola NMBL, Boiago MM, Scatolini AM, Lima TMA, Souza PA, Souza HBA
Performance, Carcass Yield, and Qualitative Characteristics of Breast and Leg Muscles of Broilers Fed Diets Supplemented w ith Vitamin E at Different Ages conversion ratio, and livability of broilers slaughtered at 45 days of age (Table 2 ).

Slaughter weight, hot and cold carcass yields, and percentage of breast and legs (Table 3 ) were not different ( $p>0.05$ ) among the experimental periods of vitamin $\mathrm{E}$ supplementation.

Considering the results presented in Table 4, higher vitamin $\mathrm{E}$ levels were observed in breast and leg muscles from supplemented birds as compared to controls. Moreover, such differences were not related to the supplementation period. There was no difference in lipid levels among the different vitamin $\mathrm{E}$ supplementation periods.

TBARS, color, and $\mathrm{pH}$ results for breast and leg muscles are shown in Tables 5 and 6 , respectively. TBA RS values at 0 day of storage were not significantly different. However, there was a positive effect $(p<0.01)$ of treatments with vitamin E supplementation on leg muscles at 3 days storage.
No significant differences were observed in muscles color and $\mathrm{pH}$ (Tables 5 and 6 ), suggesting that there was no effect of vitamin $E$ supplementation on these quality parameters.

Fatty acids profiles in breast and leg muscles are shown in Tables 7 and 8 . The results show minor differences between treatments for saturated fatty acids (SFA), monounsaturated fatty acids (MUFA), and polyunsaturated fatty acids (PUFA).

\section{DISCUSSION}

No significant differences in performance were observed between treatments. These findings are consistent with Guo et al. (2001), and similar to those reported by Nan et al. (1997), which indicates that although vitamin $E$ may be important for reducing mortality and increasing bird immunity against pathogens, no positive effects were detected on

\begin{tabular}{|c|c|c|c|c|}
\hline Treatments & FI (kg) & WG (kg) & FC $(\mathbf{k g} / \mathbf{k g})$ & Viability (\%) \\
\hline Non-supplemented & 4.27 & 2.29 & 1.87 & 96.67 \\
\hline Supplementation from 1 to 15 days & 4.45 & 2.31 & 1.93 & 94.17 \\
\hline Supplementation from 1 to 30 days & 4.38 & 2.34 & 1.87 & 99.17 \\
\hline Supplementation from 1 to 45 days & 4.27 & 2.21 & 1.93 & 98.33 \\
\hline Supplementation from 15 to 45 days & 4.38 & 2.29 & 1.91 & 95.00 \\
\hline Supplementation from 30 to 45 days & 4.30 & 2.26 & 1.90 & 96.67 \\
\hline $\mathrm{F}$ & $2.74^{\mathrm{NS}}$ & $2.40^{\mathrm{NS}}$ & $0.51^{\mathrm{NS}}$ & $1.34^{\mathrm{NS}}$ \\
\hline LSD & 0.20 & 0.13 & 0.15 & 7.40 \\
\hline CV $(\%)$ & 2.01 & 2.50 & 3.29 & 3.40 \\
\hline
\end{tabular}

NS - non-significant $(p>0.05)$.

\begin{tabular}{|c|c|c|c|c|c|}
\hline Treatments & SW (kg) & HCY (\%) & CCY (\%) & BY (\%) & LY (\%) \\
\hline Non-supplemented & 2.32 & 69.23 & 76.52 & 30.73 & 35.94 \\
\hline Supplementation from 1 to 15 days & 2.37 & 67.84 & 75.16 & 31.09 & 36.80 \\
\hline Supplementation from 1 to 30 days & 2.38 & 70.03 & 76.52 & 32.00 & 34.45 \\
\hline Supplementation from 1 to 45 days & 2.23 & 68.19 & 75.27 & 31.69 & 36.04 \\
\hline Supplementation from 15 to 45 days & 2.34 & 69.57 & 77.55 & 30.73 & 35.64 \\
\hline Supplementation from 30 to 45 days & 2.30 NS & $68.55_{\text {NS }}$ & $76.53^{N S}$ & 31.94 NS & $34.566_{\text {NS }}$ \\
\hline $\mathrm{F}$ & $1.41^{\mathrm{NS}}$ & $0.73^{\mathrm{NS}}$ & $0.65^{\mathrm{NS}}$ & $0.76^{\mathrm{NS}}$ & $1.92^{\mathrm{NS}}$ \\
\hline LSD & 0.16 & 4.46 & 5.01 & 4.02 & 2.96 \\
\hline CV $(\%)$ & 3.56 & 2.88 & 2.92 & 5.73 & 2.96 \\
\hline
\end{tabular}

NS - non-significant $(p>0.05)$.

\begin{tabular}{|c|c|c|c|c|}
\hline \multirow[t]{2}{*}{ Treatments } & \multicolumn{2}{|c|}{ Vitamin E (mg/100g) } & \multicolumn{2}{|c|}{ Lipids (\%) } \\
\hline & Breast & Leg & Breast & Leg \\
\hline Non-supplemented & $0.62 \mathrm{~d}$ & $1.92 \mathrm{e}$ & 2.31 & 7.25 \\
\hline Supplementation from 1 to 15 days & $4.20 \mathrm{~b}$ & $5.00 \mathrm{~d}$ & 2.47 & 8.29 \\
\hline Supplementation from 1 to 30 days & $3.32 \mathrm{c}$ & $7.35 \mathrm{~b}$ & 2.27 & 8.38 \\
\hline Supplementation from 1 to 45 days & $6.15 a$ & $8.02 \mathrm{a}$ & 2.59 & 7.42 \\
\hline Supplementation from 15 to 45 days & $4.02 \mathrm{~b}$ & $5.27 \mathrm{~d}$ & 2.49 & 7.33 \\
\hline Supplementation from 30 to 45 davs & $4.25 \mathrm{~b}$ & $6.15 c$ & 2.01 & 6.82 \\
\hline F & $291.29^{* *}$ & $260.65^{* *}$ & $0.36^{\mathrm{NS}}$ & $2.10^{\mathrm{NS}}$ \\
\hline LSD & 0.47 & 0.60 & 1.56 & 1.89 \\
\hline CV (\%) & 5.61 & 4.75 & 19.46 & 11.10 \\
\hline
\end{tabular}

$* *(p<0.01) ;$ NS - non-significant $(p>0.05)$. 
Leonel FR, Oba A, Pelicano ERL, Zeola NMBL, Boiago MM, Scatolini AM, Lima TMA, Souza PA, Souza HBA
Performance, Carcass Yield, and Qualitative Characteristics of Breast and Leg M uscles of Broilers Fed Diets Supplemented with Vitamin E at Different Ages

\begin{tabular}{|c|c|c|c|c|c|c|}
\hline \multirow[t]{2}{*}{ Treatments } & \multirow[t]{2}{*}{ TBARS (0 days) } & \multirow[t]{2}{*}{ TBARS (3 days) } & \multirow{2}{*}{\multicolumn{4}{|c|}{$\frac{b^{*}}{\text { (0 days) }}$}} \\
\hline & & & & & & \\
\hline Non-supplemented & 0.28 & $0.60 a$ & 46.56 & 3.25 & 4.38 & 5.99 \\
\hline Supplementation from 1 to 15 days & 0.30 & $0.50 \mathrm{ab}$ & 46.22 & 3.66 & 3.86 & 5.93 \\
\hline Supplementation from 1 to 30 days & 0.35 & $0.51 \mathrm{ab}$ & 45.84 & 3.99 & 3.79 & 5.93 \\
\hline Supplementation from 1 to 45 days & 0.33 & $0.41 b$ & 48.32 & 3.39 & 4.57 & 5.88 \\
\hline Supplementation from 15 to 45 days & 0.15 & $0.55 a$ & 46.67 & 3.64 & 4.06 & 5.91 \\
\hline Supplementation from 30 to 45 days & 0.19 & $0.49 a b$ & 46.32 & 3.14 & 4.39 & 5.87 \\
\hline $\mathrm{F}$ & $2.55^{\mathrm{NS}}$ & $5.28 * *$ & $0.85^{\mathrm{NS}}$ & $1.56^{\mathrm{NS}}$ & $0.71^{\mathrm{NS}}$ & $0.77^{\mathrm{NS}}$ \\
\hline LSD & 0.21 & 0.12 & 4.17 & 1.13 & 1.70 & 0.22 \\
\hline CV $(\%)$ & 27.46 & 10.76 & 3.96 & 14.33 & 18.08 & 1.66 \\
\hline
\end{tabular}

$* *(p<0.01) ; N S-$ non significant $(p>0.05)$.

Table 6 - TBARS ( 0 and 3 days of storage), L*(luminosity), a*(redness), b*(yellowness), and pH of leg meat of broilers supplemented with vitamin E for different periods.

\begin{tabular}{|c|c|c|c|c|c|c|}
\hline \multirow[t]{2}{*}{ Treatments } & \multirow[t]{2}{*}{ TBARS (0 days) } & \multirow[t]{2}{*}{ TBARS (3 days) } & L* & a* & b* & pH \\
\hline & & & \multicolumn{4}{|c|}{ (0 days) } \\
\hline Non-supplemented & 0.38 & $0.75 a$ & 46.56 & 8.61 & 4.38 & 6.45 \\
\hline Supplementation from 1 to 15 days & 0.35 & $0.55 b$ & 46.22 & 7.88 & 3.86 & 6.39 \\
\hline Supplementation from 1 to 30 days & 0.39 & $0.53 b$ & 45.84 & 7.62 & 3.79 & 6.34 \\
\hline Supplementation from 1 to 45 days & 0.37 & $0.49 b$ & 48.32 & 8.36 & 4.57 & 6.36 \\
\hline Supplementation from 15 to 45 days & 0.19 & $0.61 b$ & 46.67 & 7.68 & 4.06 & 6.47 \\
\hline Supplementation from 30 to 45 days & 0.17 & $0.55 b$ & 46.32 & 8.01 & 4.39 & 6.35 \\
\hline $\mathrm{F}$ & $3.75^{*}$ & $10.34 * *$ & $0.85^{\mathrm{NS}}$ & $1.10^{\mathrm{NS}}$ & $0.71^{\mathrm{NS}}$ & $1.47^{\mathrm{NS}}$ \\
\hline LSD & 0.22 & 0.13 & 4.17 & 1.66 & 1.70 & 0.21 \\
\hline CV $(\%)$ & 22.92 & 9.80 & 2.69 & 9.19 & 18.93 & 1.48 \\
\hline
\end{tabular}

$* *(p<0.01)$; NS - non significant $(p>0.05)$.

\begin{tabular}{|c|c|c|c|c|c|c|}
\hline \multirow{3}{*}{ Fatty acid } & \multicolumn{5}{|c|}{ Breast $(\mathrm{g} / 100 \mathrm{~g})$} & \multirow{3}{*}{ Suppl.30-45 days } \\
\hline & \multicolumn{5}{|c|}{$\begin{array}{c}\text { Treatments } \\
\end{array}$} & \\
\hline & NonSuppl. & Suppl.1-15 days & Suppl.1-30 days & Suppl.1-45 days & Suppl.15-45 days & \\
\hline C $14: 0$ & 0.43 & 0.43 & 0.43 & 0.44 & 0.45 & 0.43 \\
\hline C $16: 0$ & 20.02 & 20.59 & 20.17 & 19.67 & 20.02 & 20.78 \\
\hline C $16: 1$ & 2.11 & 2.58 & 2.27 & 2.01 & 2.26 & 2.72 \\
\hline C $18: 0$ & 6.86 & 6.61 & 7.03 & 7.39 & 7.15 & 6.80 \\
\hline C $18: \ln 9 \mathrm{C}$ & 28.11 & 29.62 & 28.72 & 28.57 & 28.80 & 29.75 \\
\hline C $18: 2 n 6$ & 34.87 & 33.10 & 33.91 & 34.56 & 34.87 & 33.31 \\
\hline C $18: 3 n 6$ & 0.72 & 0.82 & 0.54 & 1.12 & 0.15 & 0.22 \\
\hline C $18: 3 n 3$ & 2.11 & 1.93 & 1.94 & 1.91 & 1.93 & 1.88 \\
\hline C $20: 0$ & 0.19 & 0.12 & 0.11 & 0.14 & 0.12 & 0.12 \\
\hline C $20: \ln 9$ & 0.25 & 0.25 & 0.24 & 0.24 & 0.22 & 0.23 \\
\hline C $20: 2$ & 0.42 & 0.37 & 0.42 & 0.39 & 0.40 & 0.42 \\
\hline C $20: 3 n 6$ & 0.39 & 0.34 & 0.40 & 0.41 & 0.38 & 0.36 \\
\hline C $20: 3 n 3$ & 2.84 & 2.70 & 3.12 & 2.72 & 2.73 & 2.52 \\
\hline C $20: 4 n 6$ & 0.32 & 0.20 & 0.21 & 0.16 & 0.28 & 0.21 \\
\hline C $20: 5 n 3$ & 0.11 & 0.11 & 0.12 & - & - & - \\
\hline C $22: 6 n 3$ & 0.25 & 0.33 & 0.37 & 0.27 & 0.24 & 0.25 \\
\hline TOTAL & 100 & 100 & 100 & 100 & 100 & 100 \\
\hline SFA & 27.5 & 27.75 & 27.74 & 27.64 & 27.74 & 28.13 \\
\hline MUFA & 30.47 & 32.45 & 31.23 & 30.82 & 31.28 & 32.70 \\
\hline PUFA & 42.03 & 39.90 & 41.03 & 41.54 & 40.98 & 39.17 \\
\hline
\end{tabular}

C14:0-myristic; C16:0-palmitic; C16:1-palmitoleic; C18:0-estearic; C18:1n9C-oleic; C18:2n6-linoleic; C18:3n6-y-linolenic; C18:3n3-alfa-linolenic; C20:0-arachidic; C20:1n9-cis11-eicosenoic; C20:2-cis 11,14-eicosadienoic; C20:3n6-cis 8,11,14-eicosatrienoic; C20:3n3-cis 11,14,17-eicosatrienoic; C20:4n6-arachidonic; C20:5n3-cis 5,8,11,14,17- eicosapentaenoic; C22:6n3-cis4,7,10,13,16,19-docosahexanoic.

performance parameters.

Slaughter weights, as well as carcass and cut yields, were not influenced by vitamin E supplementation. Such results are consistent with a similar study reported by Gardini (2000).
Vitamin $E$ retention in breast and leg muscles was higher $(p<0.01)$ in birds supplemented with vitamin $E$ for 45 days. Sheehy et al. (1991), O'Neill et al. (1998), and Nan et al. (1997) reported optimal effects of vitamin E supplementation at $180-200 \mathrm{mg} / \mathrm{kg}$. It was reported 
Leonel FR, Oba A, Pelicano ERL, Zeola NMBL, Boiago MM, Scatolini AM, Lima TMA, Souza PA, Souza HBA

\begin{tabular}{|c|c|c|c|c|c|c|}
\hline \multirow{3}{*}{ Fatty acid } & \multicolumn{5}{|c|}{ Legs $(\mathrm{g} / 100 \mathrm{~g})$} & \multirow[b]{3}{*}{ Suppl.30-45 days } \\
\hline & & & $\begin{array}{l}\text { Treatme } \\
\end{array}$ & & & \\
\hline & NonSuppl. & Suppl.1-15 days & Suppl.1-30 days & Suppl.1-45 days & Suppl.15-45 days & \\
\hline C $14: 0$ & 0.42 & 0.41 & 0.43 & 0.54 & 0.40 & 0.39 \\
\hline C $16: 0$ & 19.25 & 19.85 & 19.46 & 19.01 & 18.94 & 19.28 \\
\hline C $16: 1$ & 2.75 & 3.24 & 2.85 & 2.55 & 2.83 & 3.27 \\
\hline C $18: 0$ & 6.20 & 5.94 & 6.25 & 6.45 & 6.04 & 5.81 \\
\hline C $18: 1 n 9 C$ & 29.66 & 30.79 & 30.28 & 30.17 & 30.16 & 31.25 \\
\hline C $18: 2 n 6$ & 36.67 & 34.94 & 35.85 & 36.24 & 36.52 & 35.27 \\
\hline C $18: 3 n 6$ & 0.28 & 0.27 & 0.29 & 0.27 & 0.31 & 0.26 \\
\hline C $18: 3 n 3$ & 2.27 & 2.14 & 2.17 & 2.18 & 2.18 & 2.16 \\
\hline C 20:0 & 0.12 & 0.12 & 0.12 & 0.13 & 0.12 & 0.12 \\
\hline C $20: 1 n 9$ & 0.22 & 0.23 & 0.23 & 0.23 & 0.22 & 0.23 \\
\hline C 20:2 & 0.28 & 0.25 & 0.29 & 0.29 & 0.29 & 0.29 \\
\hline C $20: 3 n 6$ & 0.27 & 0.25 & 0.29 & 0.30 & 0.29 & 0.28 \\
\hline C $20: 3 n 3$ & 1.38 & 1.33 & 1.22 & 1.35 & 1.39 & 1.48 \\
\hline C $20: 4 n 6$ & 0.13 & 0.12 & 0.15 & 0.17 & 0.22 & 0.16 \\
\hline C $20: 5 n 3$ & - & - & - & - & 0.06 & 0.04 \\
\hline C $22: 6 n 3$ & 0.10 & 0.12 & 0.12 & 0.11 & 0.10 & 0.11 \\
\hline TOTAL & 100 & 100 & 100 & 100 & 100 & 100 \\
\hline SFA & 25.99 & 26.32 & 26.26 & 26.13 & 25.70 & 25.60 \\
\hline MUFA & 32.63 & 34.26 & 33.36 & 32.95 & 33.21 & 34.35 \\
\hline PUFA & 41.38 & 39.42 & 40.38 & 40.92 & 41.09 & 40.05 \\
\hline
\end{tabular}

C14:0-myristic; C16:0-palmitic; C16:1-palmitoleic; C18:0-estearic; C18:1n9C-oleic; C18:2n6-linoleic; C18:3n6-y-linolenic; C18:3n3-alfa-linolenic; C20:0-arachidic; C20:1n9-cis11-eicosenoic; C20:2-cis 11,14-eicosadienoic; C20:3n6-cis 8,11,14-eicosatrienoic; C20:3n3-cis 11,14,17-eicosatrienoic; C20:4n6-arachidonic; C20:5n3-cis 5,8,11,14,17- eicosapentaenoic; C22:6n3-cis4,7,10,13,16,19-docosahexanoic.

that optimal levels of vitamin $E$ retention were observed around 3 e 4 weeks, respectively, in breast (14.2 and $17.1 \mathrm{ig} / \mathrm{g})$ and leg (17.3 and $20.1 \mathrm{ig} / \mathrm{g}$ ) muscles when vitamin $\mathrm{E}$ was supplemented for 5 weeks before slaughter (M orrissey et al., 1997).

Higher lipid levels found in leg as compared to breast muscles may suggest a higher probability of occurring oxidative processes in leg muscles. The present study corroborate the findings reported by Gardini (2000), in which there were no significant differences between breast and leg muscles as to lipid contents in birds supplemented with different vitamin E levels. A lower oxidation in breast and leg muscles expressed as TBARS values suggests a positive effect of vitamin $E$ during storage, especially for birds that received vitamin $\mathrm{E}$ supplementation for 45 days. In a study on the supplementation of poultry diets with vitamin $\mathrm{E}$ at $220 \mathrm{mg} / \mathrm{kg}$ for 12 days before slaughter (Webb et al., 1972), a significant reduction in lipid oxidation in breast and leg muscles was observed. O'Neill et al. (1998) reported a reduction in muscle oxidation of chickens supplemented with vitamin E at $150 \mathrm{mg} / \mathrm{kg}$. Such decrease was independent of part, supplementation period, and storage conditions, suggesting that vitamin E supplementation could be an alternative to increase the shelf-life of chicken products. Guo et al. (2001) attributed this reduction in oxidation and consequent better meat stability to the increased levels of átoco pherol in tissues. In a similar study, Bartov and Frigg
(1992) described that supplementation of vitamin $E$ at $150 \mathrm{mg} / \mathrm{kg}$ from 0 to 3 w eeks, or $100 \mathrm{mg} / \mathrm{kg}$ from 5 to 7 w eeks of age, resulted in better muscle stability against oxidation. Cortinas et al. (2005) evaluated supplementation of polyunsaturated fatty acids together with vitamin $E(0,100,200$ and $400 \mathrm{mg} / \mathrm{kg})$, and observed no improvement in oxidation stability of leg muscles of chickens fed 200 or $400 \mathrm{mg}$ vitamin E/ $\mathrm{kg}$ of diet. Carreras et al. (2004) reported that vitamin E supplementation resulted in lower TBARS levels in breast and leg muscles of broilers. The possibility of reducing peroxidation indicates the antioxidative ability of the muscle (Nuernberg et al., 2002; Lahucky et al., 2004). Although different methods of vitamin $E$ supplementation have been reported (vitamin E forms and periods of supplementation), economic aspects must be considered, as supplementation must be included in feed costs.

Quality parameters (lipid percentage, color, and $\mathrm{pH}$ ) of chicken muscles were not affected by vitamin $\mathrm{E}$ supplementation. These results are consistent with Ristic (1990), who did not observe differences in physical-chemical characteristics of breast meat of chickens supplemented for 7 days before slaughter with 40,80 , or $150 \mathrm{mg} / \mathrm{kg}$ vitamin E. Ohene-Adjei et al. (2004) did not find any differences in pork color in animals that received $0,100,200$, or $300 \mathrm{mg} / \mathrm{kg}$ of vitamin E supplementation.

The susceptibility of muscular tissue to oxidation 

Leonel FR, Oba A, Pelicano ERL,
Zeola NMBL, Boiago MM, Scatolini
AM, Lima TMA, Souza PA, Souza
HBA

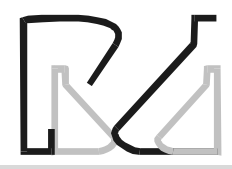

Performance, Carcass Yield, and Qualitative Characteristics of Breast and Leg M uscles of Broilers Fed Diets Supplemented with Vitamin E at Different Ages depends on several factors. However, the most important is polyunsaturated fatty acids (PUFA) muscle content (Gray et al., 1996), which is high in poultry.Some studies demonstrated that different oil sources in the diet may increase the efficiency of absorption of polyunsaturated fatty acids as compared to monounsaturated fatty acids (M arion $\&$ Woodroof, 1963; Bartov et al., 1974; Sklan et al., 1983). As a result, the percentage of unsaturated fatty acids in the carcass would increase, and the oxidative stability of the chicken carcass would be lower.

Turkeys were fed three different fat sources (soybean oil, linseed oil and lard) and two levels of vitamin E (30 and $400 \mathrm{mg} / \mathrm{kg}$ ) in a previous study (Mercier et al., 1998). There was lower oxidation of breast and leg muscles at 9 days of storage under refrigeration in the group supplemented with $400 \mathrm{mg} /$ $\mathrm{kg}$ of vitamin $\mathrm{E}$. Furthermore, there was no effect of the fat source used.

\section{CONCLUSIONS}

The supplementation of diets with vitamin $\mathrm{E}$ at 300 $\mathrm{mg} / \mathrm{kg}$ for different periods did not improve performance, yields of carcass and cuts, fatty acid profile, total lipid percentage, color, or $\mathrm{pH}$ of breast and leg muscles.

Vitamin E supplementation positively affected vitamin $E$ retention levels in breast and leg muscles. As to TBARS values, the effect was more evident in leg muscles than in breast muscle.

\section{REFERENCES}

Association of Official Analytical Chemists. Official methods of analysis of the Association of Official Analytical Chemists. Washington. $16^{\text {th }}$ ed. 1995; 1094p.

Asghar A, Lin FC, Gray IJ, Buckley JD, Booren MA. Effects of dietary oils and á-tocopherol supplementation on membranal lipid oxidation in broiler meat. Journal Food Science 1990; 55:46-50.

Bartov I, Bornstein S, Lipstein B. Effect of calorie to protein ratio on the degree of fatness in broilers fed on practical diets. British Poultry Science 1974; 15:107-117.

Bartov L, Frigg M. Effect of high concentrations of dietary vitamin $E$ during various age periods on performance, plasma vitamin $E$ and meat stability of broiler chicks at 7 weeks of age. British Poultry Science 1992; 33:393-402.

Bligh GE, Dyer JW. A rapid method of total lipid extraction and purification. Canadian Journal of Biochemistry and Physiology 1959; 37(8):911-917.
Brubacher G, Muller-Mulot W, Southgate DAT, editors. Methods for the determination of vitamins in food: recommended by Cost 91. London: Elsevier; 1985.

Burton WG, Joyce A, Ingold VK. Is vitamin E the only lipid-soluble, chain-breaking antioxidant in human blood plasma and erythrocyte membranes? Archives of Biochemistry and Biophysics 1983; 22(1):281-290.

Carreras I, Castellari M, Garcia Regueiro JA, Guerrero L, EsteveGarcia E, Sárraga C. Influence of enrofloxacin administration and á-tocopheryl acetate supplemented diets on oxidative stability of broiler tissues. Poultry Science 2004; 83:796-802.

Cortinas L, Barroeta A, Villaverde C, Galobart J, Guardiola F, Baucells $M D$. Influence of the dietary polyunsaturation level on chicken meat quality: lipid oxidation. Poultry Science 2005; 84:48-55.

Gardini CHC. Efeito da vitamina E no desempenho e na qualidade da carne de frangos de corte [dissertação] Jaboticabal (SP):Universidade Estadual Paulista; 2000.

Gray IJ, Gomaa AE, Buckey DJ. Oxidative quality and shelf life of meats. Meat Science 1996; 43:S111-S123.

Guo Y, Tang Q, Yuan J, Jiang Z. Effects of supplementation with vitamin $\mathrm{E}$ on the performance and the tissue peroxidation of broiler chicks and the stability of thigh meat against oxidative deterioration. Animal Feed Science and Technology 2001; 89:165-173.

Lahucky R, Nuernberg K, Kuechenmeister U, Bahelka I, M ojto J, Nuernberg G, Ender K. The effect of dietary magnesium oxide supplementation on fatty acid composition, antioxidative capacity and meat quality of heterozygous and normal malignant hyperthermia (MH) pigs. Arch. Tierz 2004; 47:183-191.

Lahucky R, Kuechenmeister U, Bahelka I, Novotna K, Vasickova K, Ender K. Effects of vitamin $\mathrm{E}$ by dietary supplementation and calcium ascorbate by post mortem injection muscle on the antioxidative status and on meat quality of pigs. Arch. Tierz 2005; 48:592-600.

Lauridsen C, Buckey JD, Morrisey AP. Influence of dietary fat and vitamin $\mathrm{E}$ supplementation on á-tocopherol levels and fatty acid profiles in chicken muscle membranal fractions and on susceptibility to lipid peroxidation. Meat Science 1997; 46:9-22.

Marion EJ, Woodroof GJ. The fatty acid composition of breast, thigh, and skin tissues of broilers chicken as influenced by dietary fats. Poultry Science 1963; 42:1202-1211.

Mercier Y, Gatellier P, Viau M, Remignon H, Renerre M. Effect of dietary fat and vitamin $E$ on color stability and on lipid protein oxidation in turkey meat during storage. Meat Science 1998; 48:301-318.

Monahan JF, Gray I, Asghar A, Haug A, Shi B, Bucley JD, M orrissey AP. Effect of dietary lipid and vitamin $E$ supplementation on free radical production and lipid oxidation in porcine muscle microsomal fractions. Food Chemistry 1993; 46:1-6.

Morrissey AP, Brandon S, Buckley JD, Sheery AJP, Frijj M. Tissue content of $\alpha$-tocopherol and oxidative stability of broilers receiving 


\section{Leonel FR, Oba A, Pelicano ERL, Zeola NMBL, Boiago MM, Scatolini AM, Lima TMA, Souza PA, Souza HBA}

Performance, Carcass Yield, and Qualitative Characteristics of Breast and Leg M uscles of Broilers Fed Diets Supplemented w ith Vitamin E at Different Ages

dietary $\alpha$-tocopheryl acetate supplemented for various periods preslaughter. British Poultry Science 1997; 38:84-88.

Nan TK, Lee AH, M in SB, Kang WC. Influence of dietary supplementation with linseed and vitamin $E$ on fatty acis, $\alpha$ tocopherol and lipid peroxidation in muscles of broiler chicks. Animal Feed Science and Technology 1997; 66:149-158.

Nuernberg K, Kuechenmeister U, Kuhn G, Nuernberg G, Winnefeld $K$, Ender K, Cogan U, M okady S. Influence of dietary vitamin $E$ and selenium on muscle fatty acid composition in pigs. Food Research International 2002; 35:504-510.

Ohene-Adjei S, Bertol T, Hyun Y, Ellis M, M cKeith FK, Brewer MS. Effect of vitamin $E$, low dose irradiation, and display time on the quality of pork. Meat Science 2004; 68:19-26.

O'neill ML, Galvin K, Morrissey AP, Bukley JD. Inhibition of lipid oxidation in chicken by cernosine and alpha-tocopherol supplementation and determination by derivative spectrophometry. Meat Science 1998; 50:479-488.

Papas AM. Vitamin E and exercise: aspects of biokinetics and bioavailability. World Ver. Nutr. 1993; 72:165-176.

Pearson MA, Gray I, Wolzak MA, Horenstein NA. Safety implications of oxidized lipids in muscle foods. Food Technology 1983; 37:121130.

Pikul J, Leszczynski ED, Kummerow AF. Evaluation of tree modified TBA methods for measuring lipid oxidation in chicken meat. Journal of Agricultural and Food Chemistry 1989; 37:1309-1313.

Ristic ME. Influb der vitamin E versorgung auf Fleischqualität van broiler. In: Proceedings of the 8th of European Poultry Conference; 1990; Barcelona, Spain. p.232-235.

Rostagno SH. Tabelas brasileiras para aves e suínos. Viçosa(M G) : Universidade Federal de Viçosa; 2000.

Sheehy AJP, M orrissey AP, Flynn A. Influence of dietary á-tocopherol concentrations in chicken tissues. British Poultry Science 1991; 32:391-397.

Skan D,Tenne E, Budowski P. The effect of dietary fat and tocopherol on lipolysis and oxidation in turkey meat stored at different temperatures. Poultry Science 1983; 62(5):2017-2021.

Webb EJ, Brunson CC, Yates DJ. Effects of feeding antioxidants on rancidity development in pre-cooked, frozen broiler parts. Poultry Science 1972; 51:1601-1605.

Yamauchi K, M urata M, Ohashi T, Katayama H, Pearson M A, Okada T, Yamakura T. Effect of dietary á-tocopherol supplementation on the molar ratio of polyunsaturated fatty acids/á-to copherol in broiler skeletal muscles and subcellular membranes and its relationship to oxidative stability. Nippon Shokuhin Kogyo Gakkaishi 1991; 38:545-552. 